\title{
Will your business insurance reimburse you for Covid-19 losses?
}

\author{
Angel Reyes (Reyes Browne Reilley Law Firm) \\ Benjamin Hunter (University of Michigan Law School)
}

KEYWORDS: Banking, Finance, Insurance, Family Business, crisis management, Family Business Consulting.

The effects of the Covid-19 pandemic are all over the American business community. With millions sick and hundreds of thousands of fatalities worldwide, this virus is having an impact that would have been unimaginable just a few months ago. In response to this crisis, state and local governments across the United States implemented orders that required non-essential business to shut their doors and cease doing business. Those actions had a disastrous effect on businesses of all sizes because as they can no longer bring in cash to pay their bills. Many business owners are now turning to their business interruption insurance policies to try to stay afloat during this crisis.

The two most common types of business interruption insurance that business owners should sue to recover under are 1) policies that cover physical damage or loss and 2) policies that cover actions by civil authorities that limit business activity. In addition, insurance policies occasionally have endorsements that cover virus and disease. The language of the policy will be important for any business owner bringing a lawsuit against their insurance company. No matter, courts have found in favor of business owners making these types of claims under a variety of different policies.

Unfortunately, for most business owners, their business interruption insurance claims were denied as insurance companies sought to limit their losses around the COVID-19 pandemic business shutdowns. Insurance companies estimate that the cost of covering these claims would be between $\$ 110$ billion and $\$ 290$ billion per month. However, insurance companies denying these claims is not the end of the story. There is a body of law supporting coverage in situations like this. That body of law gives business owners a strong case that they should be able to recover under their insurance policies. Although the outcome of a lawsuit would of

course depend on the language of the individual insurance policy, almost all property and casualty insurance policies contain language for business interruption loss of income, and courts across the country have ruled in favor of business owners in situations similar to the current crisis.

Business owners should also know there are a few factors besides these court cases that weigh in favor of business owners trying to make these claims. First, courts will interpret insurance policies in favor of the policyholder when there is any ambiguity in the language. Additionally, two federal bills have been introduced that would guarantee business interruption coverage for Covid-19 related losses. State legislatures are also responding, with states including Louisiana, Massachusetts, New Jersey, New York, Ohio, Pennsylvania, Michigan, and South Carolina introducing similar bills. If those bills become law, then businesses will have a much easier time recovering money from their insurance carriers.

\section{Business Interruption Insurance}

Business interruption insurance is included with most commercial insurance policies. Its purpose is to replace lost income when a business is forced to stop business operations and suffers a loss of income as a result. The exact coverage will vary between different policies, but policies can cover costs such as lost profits, fixed costs, temporary relocation, wages, commission and training costs, losses from closures due to civil authority orders, taxes, and loan payments.

State law controls interpretation of insurance policies, and some states have been more willing to let businesses recover when the physical damage or loss is less obvious. In Netherlands Ins. Co. v. Main Street Ingredients, LLC, Main Street Ingredients was seeking 
insurance coverage for powdered milk that it thought contaminated with salmonella. The insurance company argued that because the milk tested negative for salmonella, there was no property damage. The court disagreed and held that because Main Street Ingredient's insurance policy used the wording "physical injury" instead of "direct physical loss," the lack of physical damage did not void Main Street's insurance claim. Instead, the case turned on the fact that there was a risk of salmonella because the milk was manufactured in "insanitary" conditions, which the court viewed as a physical injury. This shows that in some jurisdictions, business owners will not have to prove actual physical damage to their businesses, depending on their insurance policies and their state's law.

Physical loss or damage of some kind is typically a threshold requirement for businesses to recover under their business interruption insurance policies. In Source Food Technology, Inc. v. United States Fid. and Guar. Co., a meat processing company was unable to receive shipments of beef because of a government ordered embargo on Canadian beef. Source Food Technology was not able to recover under their business interruption insurance because the beef was not actually contaminated; there was simply a risk of contamination. According to the court, because the beef did not suffer actual physical damage, Source Food Technology would not covered by their insurance. This court took a strict view of the physical damage requirement. Nevertheless, other courts have interpreted the physical damage or loss requirement in ways more favorable to business owners making insurance claims.

While physical loss or damage is a threshold requirement for making an insurance claim of this type courts will apply that rule differently in different jurisdictions and under different insurance policies. If courts apply it like the court in Main Street Ingredient's case, then business owners will have a strong argument in favor of recovery if they can make the case that there was a physical injury to their property due to it being in unsafe or insanitary conditions. If the court takes a stricter view that is more in line with Source Food Technology, then business owners still have other arguments available to them that will allow them to recover. Next, we will look at how business owners should argue that their property was physically damaged by the Covid-19 pandemic.

\section{Covid-19 Contamination}

Even if the insurance policy requires actual physical loss or damage, Covid-19 contamination will count as physical loss or damage in many states. A number of court cases have supported the idea that contamination from harmful substances is physical damage for the purpose of an insurance policy. If business owners were forced to close their doors because they believed that their premises or inventory was contaminated by Covid-19, they would have a strong argument for recovery under physical loss or damage insurance policies in many states.

Contamination of inventory was found to constitute physical damage in some cases. In General Mills, Inc. v. Gold Medal Ins. Co., General Mills had an insurance policy that covered direct physical loss or damage to insured property. Some of their grain was contaminated with an unapproved pesticide, and the court held that because the grain could not be used in their business, that was sufficient to support a finding of physical damage. A business owner could make the argument that because their inventory was contaminated by exposure to the Covid-19 virus, the business suffered physical loss or damage, thereby making it eligible to make an insurance claim.

Other courts across the country have come to similar conclusions with regard to the business premises, with most cases requiring that the building be rendered uninhabitable or unusable. In Port Auth. Of New York \& New Jersey v. Affiliant FM Ins. Co. , the court found that asbestos contamination in the air of the building was a direct physical loss to the owner because it made the structure uninhabitable and unusable. Another case, Prudential Prop. \& Cas. Co. v. Lillard-Roberts, stated that the owner of a building suffered a direct physical loss because the property was uninhabitable due to mold. Moreover, in Gregory Packaging, Inc. $v$. Travelers Prop. Cas. Co. of America, ammonia was released into a factory, forcing it to be evacuated and professionally cleaned. The court held that they sustained direct physical loss to their property because of the ammonia leak.

These cases are good news for business owners who should argue that their businesses were contaminated by Covid-19. Under these cases, business owners would be able to recover business interruption insurance when their property, whether it be their inventory or the business premises, was contaminated or exposed to the Covid-19 virus, because that would 
constitute physical damage or loss.

Not all jurisdictions have been as quick to count contamination as physical loss or damage. In Universal Image Prod., Inc. v. Federal Ins. Co., the court held that the policyholder was not covered under a "direct physical loss or damage" insurance clause when their building became contaminated with mold and bacteria. The court reasoned that because there was no tangible damage to the physical property, and the premises were not rendered unusable or uninhabitable, they were not covered under their insurance policy. However, that does not mean that businesses in the $6^{\text {th }}$ Circuit are out of luck. A strong argument should be made that Covid-19 is different from the contamination discussed in this case, because any Covid-19 contamination puts the lives of workers at risk, which would mean that the building is unusable until it has been disinfected. The mold in this case was not life-threatening, making it less of a threat to workers than Covid-19 contamination.

The simple fact that courts disagree on the definition of physical loss or damage will be helpful to some business owners making Covid-19 contamination claims. In insurance law, ambiguities in the language of the insurance policy are construed in favor of the policyholder. In Murray v. State Farm Fire \& Cas. Co., the court stated that provisions in an insurance policy may be deemed ambiguous if courts in other jurisdictions have interpreted the provision in different ways. As shown in the cases above, there is a disagreement among courts over the meaning of physical loss or damage. In jurisdictions following this rule, business owners should argue that because there is disagreement in other courts about whether contamination counts as physical damage, that makes their insurance policy ambiguous, and therefore, the policy is interpreted in their favor.

In short, if a business owner has an insurance policy that only covers physical loss or damage, they still have a strong case to recover business interruption insurance if they believe that there was Covid-19 contamination, to either the inventory or the premises. Although some jurisdictions have rejected the argument that contamination constitutes physical loss or damage, the life-threatening and unprecedented nature of the Covid-19 pandemic may convince even those reluctant courts to agree that contamination counts as a physical loss.

\section{Civil Authority Insurance}

In the absence of suspected Covid-19 contamination or other physical damage, business owners may have another avenue for recovery under their business interruption insurance policies. Civil authority insurance is a type of business interruption insurance which is included in many insurance policies that comes into effect when the government prohibits access to a business. With state and local governments ordering the closure of non-essential businesses across the country, this may be the best way for some businesses to recover under their insurance policies.

Generally, courts look for three requirements when deciding civil authority insurance cases. First, they ask if the loss to the business was caused by government action that denied access to the insured premises. Second, they determine if the government took that action because of direct physical loss or damage to property other than the insured premises. The scope of the second requirement depends on the individual insurance policy. In some cases, the damaged property must be adjacent to the insured premises. In other cases, the property does not have to be adjacent to the premises and the government action can be in response to any property damage. Lastly, civil authority insurance policies usually require that the physical damage result from a covered cause of loss.

Government orders that have required businesses to stay closed due to the Covid-19 pandemic satisfy the first general requirement of civil authority insurance coverage. In order to recover under a civil authority insurance policy, there must be government action that prohibits access to the business. In Southern Hospitality, Inc. v. Zurich American Ins. Co., a hotel operator tried to recover under their civil authority business interruption insurance policy. Commercial flights had been shut down in the wake of the September $11^{\text {th }}$ terrorist attacks, and Southern Hospitality's hotels were greatly impacted by the lack of tourists. The court ruled against Southern Hospitality because access had been denied to flights, not to their hotels. In Kean, Miller v. National Fire Ins. Co. of Hartford, the court stated that there must be a "direct nexus between the civil authority order/action and the suspension of the insured's business." Even under the strictest interpretations of this requirement, business owners will be able to argue that the civil authorities actually prohibited access, because state and local governments across the country have ordered 
businesses to close under threat of fines and other legal penalties. Unlike in Southern Hospitality, business owners will not be arguing that they lost business as a result of another industry being impacted by government orders. They will be able to argue that their actual businesses were closed by government order, which satisfies the first requirement of a civil authority claim.

The second general requirement for civil authority insurance is that the government prohibited access to the business due to property damage. Different insurance policies have different requirements on what property needs to be damaged. In United Air Lines, Inc. v. Inss Co. of the State of Pennsylvania, United was making a civil authority insurance claim after the September $11^{\text {th }}$ terrorist attacks. Ronald Reagan Washington National Airport was closed and United sought coverage due to lost earnings from the closure of the airport. United lost the case because their insurance policy required damage to their property or to adjacent property. Since there was no damage to the airport or adjacent to it, United was unable to recover under their civil authority insurance. Nevertheless, even if an insurance policy only allows for civil authority insurance when adjacent property is physically damaged, business owners should still argue that businesses in their area were physically damaged by Covid-19 contamination.

Other insurance policies are more lenient about which property must be damaged for civil authority insurance to be available. In Assurance Co. of America v. BBB Service Company, BBB sought to recover under their civil authority insurance policy when a hurricane prompted local governments in Georgia to preemptively close businesses in the storm's path. The property that was damaged was hundreds of miles away, but BBB was still able to recover because their insurance policy just required that some property be damaged, not adjacent property. In this case, business owners could argue that the government orders closing down businesses were in response to physical damage across the country from the Covid-19 pandemic.

The physical damage to property must be caused by a covered cause of loss as listed in the insurance policy. In Cleland Simpson Co. v. Fireman's Ins. Co., the city government ordered that businesses close because a hurricane and resulting flooding had destroyed water mains, which would have hindered the city's ability to fight a fire. The court held that there was no damage resulting from a covered cause of loss because the business's insurance policy covered damage from fire, but not damage from the danger of fire. Insurance companies have used this case to try to deny coverage under civil authority clauses. In Narricot Indus., Inc. $v$. Fireman's Fund Ins. Co., the insurance company compared their situation to Cleland Simpson, and argued that because the civil authority's actions were "preventative," the damage did not result from a covered cause of loss. However, the court did not accept that argument, because the civil authority's actions were still as a result of the covered cause of loss. Business owners hoping to recover under their civil authority insurance should argue that the civil authority's actions resulted from the pandemic because the danger that they were trying to prevent, the spread of the disease, actually occurred, unlike in Cleland Simpson, where there was never actually a fire.

If businesses have civil authority insurance, they have a strong argument that they should be able to recover due to losses caused by government ordered shutdowns. While Covid-19 related shutdowns are unprecedented, in both how widespread they are, and how long they are in place for, this is the type of situation that businesses expect to be covered by civil authority insurance, and courts are favorable toward reasonable and expected interpretations of insurance policies.

\section{Legislation and Government Response}

Many states legislatures have proposed laws that would guarantee business interruption insurance coverage to businesses that suffered losses due to the Covid-19 pandemic. Those states include Louisiana, Massachusetts, New Jersey, New York, Ohio, Pennsylvania, Michigan, and South Carolina. Mike Thompson, a congressional representative from California, has also introduced a bill in the House of Representatives that would guarantee business interruption coverage to businesses due to the pandemic. Carolyn Maloney of New York introduced a bill that would provide federal funding to insurance companies that provide pandemic coverage introduced another bill. These bills would provide a major boost to businesses seeking recovery under their business interruption insurance policies, but as of now, they are still going through the legislative process.

Unfortunately for business owners, some other states' 
officials are stressing that Covid-19 related losses should not be covered. The insurance commissioners of Arkansas, Georgia, Kansas, Maryland, West Virginia, and North Carolina have all issued statements bringing up various issues with insurance companies providing coverage in this situation. Some of the issues those insurance commissioners mention are that many business insurance policies contain exclusions for communicable disease, that it will be difficult to prove physical damage, and the massive cost to insurance companies.

Still, legislation is moving forward in states and at the federal level that would extend coverage to businesses during this trying time. Because the pandemic and ensuing shutdown have been so unprecedented and had such a massive impact on businesses in this country, it seems likely that the federal and state governments will find a way to give business owners some relief.

\section{Conclusion}

Businesses are facing a massive challenge trying to survive shutdowns. The situation would be much worse if they could not recover under their business interruption insurance policies. Luckily, there is plenty of legal support for businesses to sue their insurance companies for denying these claims. Although the terms of the insurance policies and local laws will affect the outcome of these cases, courts across the country have found in favor of businesses in cases like these, and business owners should not give up just because their insurance companies denied their claim initially.

\section{References}

https://www.investopedia.com/terms/b/business-

interruption-insurance.asp

https://www.investopedia.com/terms/c/civil-authorityclause.asp

https://www.cpajournal.com/2020/04/29/will-business-in terruption-insurance-provide-coverage-for-coronaviruslosses/

https://www.natlawreview.com/article/state-insurance-c ommissioners-issue-notices-regarding-business-

interruption-coverage Source Food Tech., Inc. v. U.S. Fid. \& Guar. Co., 465 F.3d 834 (8th Cir. 2006). Netherlands Ins. Co. v. Main St. Ingredients, LLC, 2013 WL 101876 (D. Minn. Jan. 8, 2013), aff'd, 745 F.3d 909 (8th Cir. 2014). Gen. Mills, Inc. v. Gold Medal Ins. Co., 622 N.W.2d 147 (Minn. Ct. App. 2001).

Port Auth. of New York \& New Jersey v. Affiliated FM Ins. Co., 311 F.3d 226 (3d Cir. 2002). Prudential Prop. \& Cas. Ins. Co. v. Lillard-Roberts, 2002 WL 31495830 (D. Or. June 18, 2002). Gregory Packaging, Inc. v. Travelers Prop. Cas. Co. of Am., 2014 WL 6675934 (D.N.J. Nov. 25, 2014).

Universal Image Prods., Inc. v. Fed. Ins. Co., 475 F. App'x 569 (6th Cir. 2012).

Murray v. State Farm Fire \& Cas. Co., 509 S.E.2d 1 (W. Va. 1998).

S. Hosp., Inc. v. Zurich Am. Ins. Co., 393 F.3d 1137 (10th Cir. 2004).

Kean, Miller, Hawthorne, D'Armond McCowan \& Jarman, LLP v. Nat'I Fire Ins. Co. of Hartford, 2007 WL 2489711 (M.D. La. Aug. 29, 2007).

United Air Lines, Inc. v. Ins. Co. of State of PA, 439 F.3d 128 (2d Cir. 2006).

Assurance Co. of Am. v. BBB Serv. Co., 593 S.E.2d 7 (Ga. App. 2003).

Cleland Simpson Co. v. Firemen's Ins. Co. of Newark, 11 Pa. D. \& C.2d 607 (Pa. Com. PI.), aff'd sub nom. Cleland Simpson Co. v. Firemen's Ins. Co. of Newark, N. J., 392 Pa. 67, 140 A.2d 41 (1958).

Narricot Indus., Inc. v. Fireman's Fund Ins. Co., 2002 WL 31247972 (E.D. Pa. Sept. 30, 2002).

Additional search terms: business interruption loss of income lawsuits, business interruption insurance claims, loss of income for business interruption claims. 